\title{
Flavobacterium ceti sp. nov., isolated from beaked whales (Ziphius cavirostris)
}

\author{
A. I. Vela, ${ }^{1}$ A. Fernandez, ${ }^{2}$ C. Sánchez-Porro, ${ }^{3}$ E. Sierra, ${ }^{2}$ M. Mendez, ${ }^{2}$ \\ M. Arbelo, ${ }^{2}$ A. Ventosa, ${ }^{3}$ L. Domínguez ${ }^{1}$ and J. F. Fernández-Garayzábal ${ }^{1}$
}

Correspondence

J. F. Fernández-Garayzábal garayzab@vet.ucm.es

\author{
${ }^{1}$ Departamento de Sanidad Animal, Facultad de Veterinaria, Universidad Complutense, 28040 \\ Madrid, Spain \\ ${ }^{2}$ Departamento de Anatomía Patológica, Instituto Universitario de Sanidad Animal, Facultad de \\ Veterinaria, Universidad de Las Palmas de Gran Canaria, 35016 Gran Canaria, Spain \\ ${ }^{3}$ Departamento de Microbiología y Parasitología, Facultad de Farmacia, Universidad de Sevilla, \\ 41012 Sevilla, Spain
}

\begin{abstract}
Three isolates of a Gram-negative, catalase- and oxidase-positive, rod-shaped bacterium, isolated from the lung and liver of two beaked whales, were characterized by phenotypic and molecular genetic methods. Based on cellular morphology and biochemical criteria, the isolates were tentatively assigned to the family Flavobacteriaceae, although they did not appear to correspond to any recognized species. Comparative 16S rRNA gene sequencing showed that the three new isolates shared $100 \%$ sequence similarity. The unknown bacterium was phylogenetically closely related to, but distinct from the type strains of Flavobacterium johnsoniae $(93.7 \%$ sequence similarity), Flavobacterium frigidimaris (93.4\%), Flavobacterium aquidurense (93.4\%), Flavobacterium hibernum (93.4\%) and Flavobacterium degerlachei (93.4\%). The novel isolates were readily distinguished from these and other related Flavobacterium species by physiological and biochemical tests. On the basis of phenotypic and phylogenetic evidence, it is proposed that the unknown isolates from whales are classified as a novel species of the genus Flavobacterium, Flavobacterium ceti sp. nov. The type strain is $454-2^{\top}\left(=\mathrm{CECT} 7184^{\top}\right.$ =CCUG 52969 ${ }^{\mathrm{T}}$ ).
\end{abstract}

The genus Flavobacterium (Bergey et al., 1923; Bernardet et al., 1996; Bernardet \& Bowman, 2006) is the type genus of the family Flavobacteriaceae, which currently comprises more than 25 other genera (Bernardet et al., 1996; Bernardet \& Nakagawa, 2006). Members of the genus Flavobacterium are widely distributed in nature, especially in cold marine environments (Bernardet \& Bowman, 2006). Most species of Flavobacterium are harmless, but some are opportunistic or true pathogens. Flavobacterium psychrophilum, Flavobacterium branchiophilum and Flavobacterium columnare are fish-pathogenic species responsible for various diseases in salmonids and other fish species. Flavobacterium hydatis and Flavobacterium succinicans have also been isolated from diseased salmon, but the pathogenicity of these two species has not been clearly demonstrated (Bernardet \& Bowman, 2006). Only one questionable case of human lung disease associated with Flavobacterium species has been reported (Bernardet \& Bowman, 2006). In this study, we report the phenotypic

The GenBank/EMBL/DDBJ accession number for the 16S rRNA gene sequence of strain $454-2^{\top}$ is AM292800. and phylogenetic features of three bacterial strains isolated from two beaked whales.

The bacterial strains (designated 453-2, 453-5 and 454- $2^{\mathrm{T}}$ ) were isolated from the liver $\left(454-2^{\mathrm{T}}\right.$ and 453-2) and lung (453-5) of two stranded beaked whales (Ziphius cavirostris) found along the coast of the Canary Islands (Spain). The two animals showed no clinical signs of disease and no apparent lesions were observed after post-mortem examination. Isolate $454-2^{\mathrm{T}}$ was recovered in pure culture, while the other two isolates were obtained in mixed culture with members of the genus Vibrio. Samples were collected and frozen at $-40{ }^{\circ} \mathrm{C}$ until being processed in the laboratory. Strains were isolated on Columbia blood agar plates (bioMérieux) after incubation at $37{ }^{\circ} \mathrm{C}$ for $24 \mathrm{~h}$ under aerobic conditions.

The isolates were tested for a number of key characteristics by using standard procedures (Smibert \& Krieg, 1994; Bowman et al., 1996, Bowman, 2000), such as Gram staining, production of catalase and oxidase and hydrolysis of agar, alginate, casein, L-tyrosine, pectin, aesculin, CMcellulose, DNA, urea, gelatin and starch. Growth in brain heart infusion broth was assessed at 4, 15, 22, 30, 37 and 
$42{ }^{\circ} \mathrm{C}$, with 3, 4.5 and $6.5 \%$ added $\mathrm{NaCl}$ and under anaerobic (with 4-10\% $\mathrm{CO}_{2}$ ) and microaerobic (with 5$15 \% \mathrm{O}_{2}$ and 5-12\% $\mathrm{CO}_{2}$ ) conditions, using GasPak Plus and CampyPak Plus systems (BBL), respectively. Growth was tested on MacConkey (bioMérieux), nutrient (Difco), trypticase soy (bioMérieux) and marine (Difco) agars. The presence of gliding motility and the production of flexirubin-type pigments and extracellular glycans were investigated following the minimal standards for the description of new taxa in the family Flavobacteriaceae (Bernardet et al., 2002). The strains were characterized biochemically using the API 20NE, API 20E and API ZYM systems (bioMérieux) according to the manufacturer's instructions, except that the incubation temperature for API 20NE was $37^{\circ} \mathrm{C}$. Using the miniaturized biochemical kits, the isolates displayed identical phenotypic profiles. A detailed description of the morphological, physiological and biochemical characteristics of the isolates is given in the species description and in Table 1.

To establish the phylogenetic affinities of the unknown isolates, their $16 \mathrm{~S}$ rRNA gene sequences were determined as described previously (Vela et al., 2005) and subjected to a comparative analysis. The almost-complete sequences ( $>1400$ nucleotides) of the three strains were determined and pairwise analysis revealed that the 16S rRNA gene sequences of the strains were identical. Sequence searches of GenBank using the program FASTA (Pearson, 1994) showed that the isolates were most closely related to members of the family Flavobacteriaceae. The isolates exhibited the highest levels of $16 \mathrm{~S}$ rRNA gene sequence similarity with the type strains of Flavobacterium johnsoniae (93.7\% sequence similarity), Flavobacterium frigidimaris (93.4\%), Flavobacterium aquidurense (93.4\%), Flavobacterium hibernum (93.4\%) and Flavobacterium degerlachei $(93.4 \%)$. These sequences and those of other known related strains were retrieved from GenBank and aligned with the newly determined sequences using the program DNATools (Rasmussen, 1995). Phylogenetic trees were constructed according to three different algorithms: neighbour-joining (Saitou \& Nei, 1987) using the programs DNATools and TreeView (Page, 1996), maximumlikelihood using the PHYML software (Guindon \& Gascuel, 2003) and maximum-parsimony using the software

Table 1. Characteristics that differentiate Flavobacterium ceti sp. nov. from related Flavobacterium species

Strains: 1, 454-2 ${ }^{\mathrm{T}}$ (F. ceti sp. nov.); 2, F. frigidimaris KUC-1 ${ }^{\mathrm{T}}$; 3, F. aquidurense (5 strains); 4, F. saccharophilum IAM 14309 ${ }^{\mathrm{T}}$; 5, F. hibernum ACAM $376^{\mathrm{T}} ; 6$, F. gelidilacus LMG $21477^{\mathrm{T}}$; 7, F. hercynium (5 strains); 8, F. hydatis IAM $12365^{\mathrm{T}} ; 9$, F. weaverense AT1042 ${ }^{\mathrm{T}} ; 10$, F. flevense DSM $1076^{\mathrm{T}} ; 11$, F. degerlachei (14 strains); 12, F. daejeonense GH1-10 ${ }^{\mathrm{T}}$; 13, F. johnsoniae DSM 2064 ${ }^{\mathrm{T}}$. Data from this study and from Bernardet et al. (1996), McCammon et al. (1998), Van Trappen et al. (2003, 2004), Nogi et al. (2005), Bernardet \& Bowman (2006), Kim et al. (2006), Yi \& Chun (2006) and Cousin et al. (2007). All taxa have MK-6 as major respiratory quinone. +, Positive reaction; -, negative ; (+), weakly positive ; v, variable; tr, traces $(<1 \%$ of total); ND, no data available.

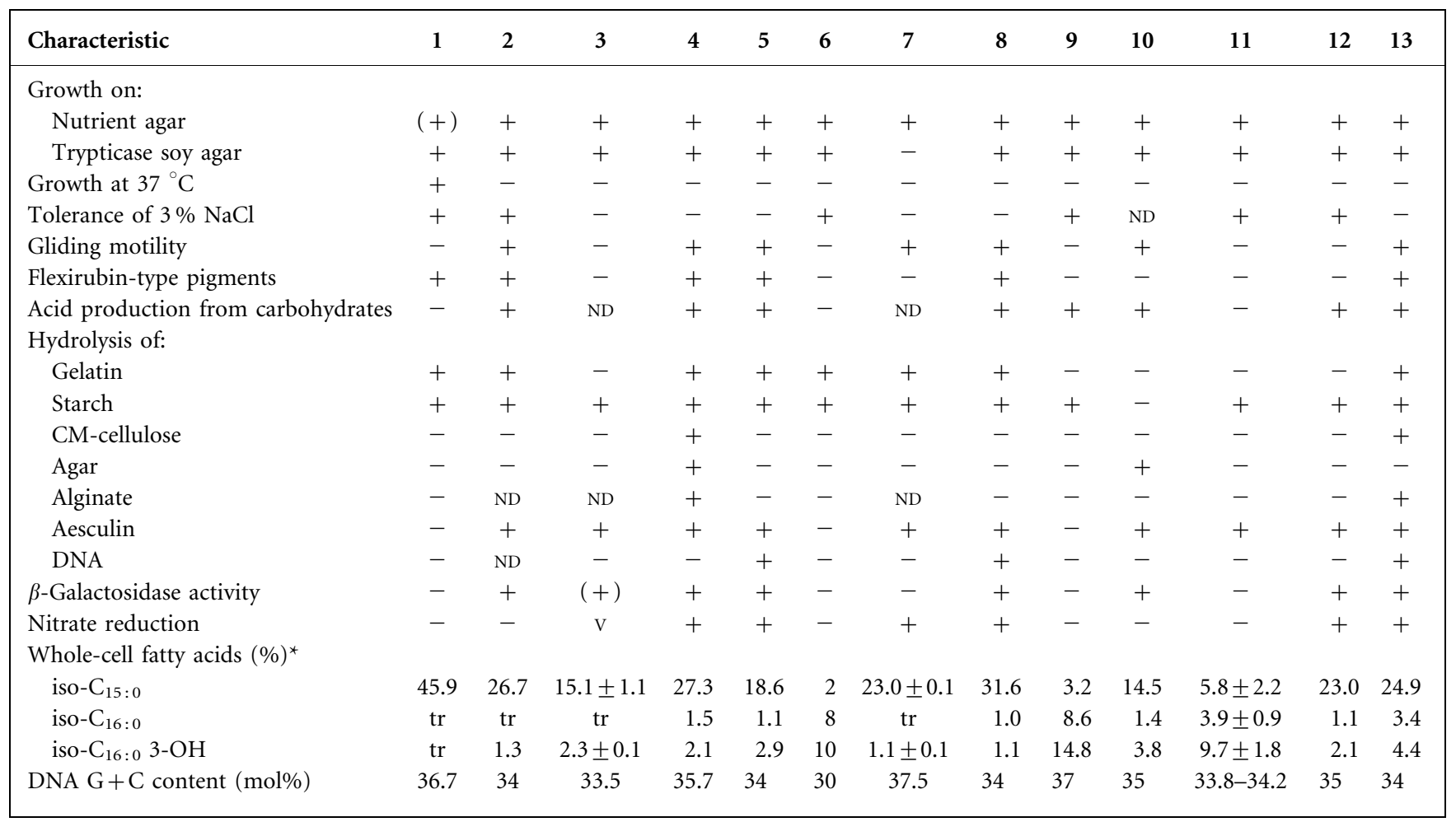

${ }^{\star}$ Different growth conditions were used for analysis of the fatty acids of the strains listed. 
package MEGA version 3.1 (Kumar et al., 2004). Genetic distances for the neighbour-joining and maximum-likelihood algorithms were calculated by the Kimura twoparameter method (Kimura, 1980) and close-neighbour interchange ( search level $=2$, random additions $=100$ ) was applied in the maximum-parsimony analysis. The stability of the groupings was estimated by bootstrap analysis (1000 replications). The phylogenetic tree based on the neighbour-joining algorithm (Fig. 1) showed that the new isolates (as exemplified by strain $454-2^{\mathrm{T}}$ ) formed a separate branch that was further grouped with the recognized species of the genus Flavobacterium, which was supported

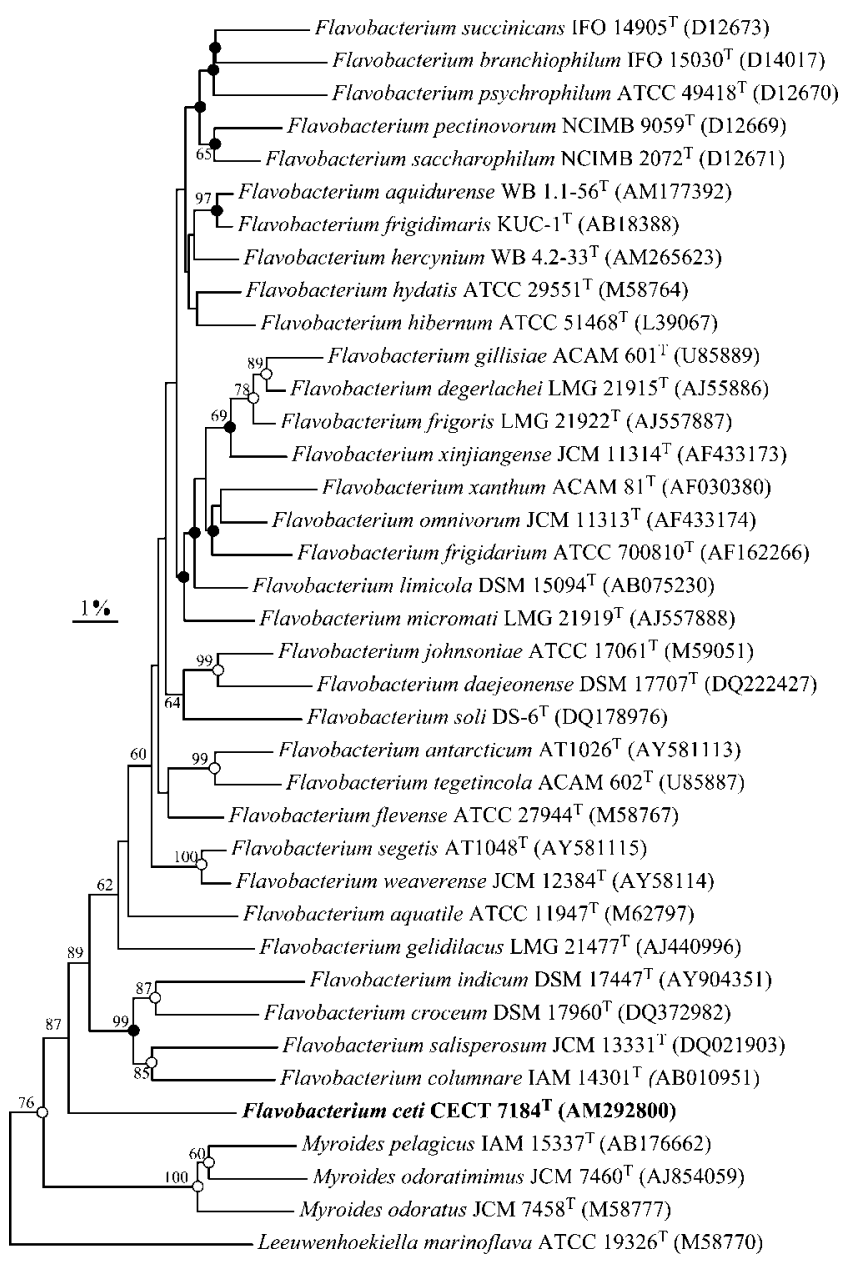

Fig. 1. Phylogenetic tree based on 16S rRNA gene sequence comparison obtained with the neighbour-joining algorithm showing the relationships of strain $454-2^{\top}$ to closely related taxa. Bootstrap values (expressed as percentages of 1000 replications) $>50 \%$ are given at branching points. Solid circles indicate that the corresponding nodes (groupings) are also obtained on the maximum-likelihood tree. Open circles indicate that the corresponding nodes (groupings) are also obtained on the maximumlikelihood and parsimony trees. Leeuwenhoekiella marinoflava ATCC $19326^{\top}$ was used as an outgroup. Bar, $1 \%$ sequence divergence. by a bootstrap resampling value of $87 \%$. Strain $454-2^{\mathrm{T}}$ formed a peripheral branch in the FlavobacteriumMyroides cluster in the maximum-likelihood tree, while it was recovered with species of the genus Myroides in the maximum-parsimony tree. These phylogenetic relationships were not supported by bootstrap resampling (44 and $43 \%$, respectively). Moreover, the unknown isolates were excluded from the genus Myroides based on phenotypic considerations (Bernardet et al., 1996; Vancanneyt et al., 1996; Yoon et al., 2006). For example, in contrast to members of the genus Myroides, the new isolates grew weakly under microaerobic conditions and failed to grow in broth containing $6.5 \% \mathrm{NaCl}$ and on MacConkey agar.

Although the new isolates had a $16 \mathrm{~S}$ rRNA gene sequence similarity lower than $94 \%$ to members of the genus Flavobacterium, a value well below the cut-off recommended for delineation of genomic species (Wayne et al., 1987), DNA-DNA hybridization experiments were carried out between the three isolates (strains $454-2^{\mathrm{T}}, 453-2$ and 453-5) and between strain $454-2^{\mathrm{T}}$ and its nearest phylogenetic neighbour, F. johnsoniae ATCC $17061^{\mathrm{T}}$. DNA was extracted and purified by the method of Marmur (1961). DNA-DNA hybridization studies were carried out by the membrane method of Johnson (1994), described in detail by Arahal et al. (2001). The hybridization experiments were carried out under optimal conditions, at a temperature of $49.5{ }^{\circ} \mathrm{C}$, which is within the limits of validity for the filter method (De Ley \& Tijtgat, 1970). The percentage of hybridization was calculated as described by Johnson (1994). Three independent determinations were carried out for each experiment and the results reported are mean values. The DNA-DNA hybridization study between the three new isolates showed 98$100 \%$ DNA relatedness to each other, demonstrating that they are members of the same species (Wayne et al., 1987). The DNA-DNA reassociation value between strain $454-2^{\mathrm{T}}$ and the type strain of $F$. johnsoniae (ATCC $17061^{\mathrm{T}}$ ) was $15 \%$, clearly confirming that the new isolates constitute a separate species (Wayne et al., 1987).

The $\mathrm{G}+\mathrm{C}$ content of the DNA was determined from the mid-point value $\left(T_{\mathrm{m}}\right)$ of the thermal denaturation profile (Marmur \& Doty, 1962) obtained with a Perkin-Elmer UVVis Lambda 20 spectrophotometer at $260 \mathrm{~nm}$. The $\mathrm{G}+\mathrm{C}$ content of the three isolates ranged from 36.4 to $37.2 \mathrm{~mol} \%$, values that were confirmed in three different assays. This DNA G $+\mathrm{C}$ range is consistent with that of members of the genus Flavobacterium (Bernardet \& Bowman, 2006).

The determination of the respiratory quinone of one representative isolate (strain $454-2^{\mathrm{T}}$ ) was carried out by the identification service of the DSMZ (Braunschweig, Germany). The major quinone was MK-6, in accordance with all members of the family Flavobacteriaceae (Bernardet \& Nakagawa, 2006). Cellular fatty acid analysis of strain $454-2^{\mathrm{T}}$, grown on blood agar at $30{ }^{\circ} \mathrm{C}$ for $48 \mathrm{~h}$ under aerobic conditions, was performed as described by 
Kämpfer \& Kroppenstedt (1996). The major fatty acids of strain $454-2^{\mathrm{T}}$ were branched and hydroxy acids. The predominant fatty acids were iso- $\mathrm{C}_{15: 0}(45.9 \%)$, iso$\mathrm{C}_{17: 1} \omega 9 c(18.9 \%)$, iso- $\mathrm{C}_{17: 0} 3-\mathrm{OH}(11.6 \%)$ and summed feature $4\left(\mathrm{C}_{16: 1} \omega 7 c /\right.$ iso- $\left.\mathrm{C}_{15: 0} 2-\mathrm{OH}\right)(11.5 \%)$. The isolate also contained moderate or small amounts of iso- $\mathrm{C}_{15: 0} 3$ $\mathrm{OH}(3.7 \%), \mathrm{C}_{15: 0}(1.8 \%)$ and an unknown fatty acid with an equivalent chain length of $13.566(1.2 \%)$. This fatty acid profile is in accordance with those of members of the genus Flavobacterium (Bernardet et al., 1996, 2002; Bernardet \& Bowman, 2006), although the proportions of some of the predominant fatty acids, such as iso- $\mathrm{C}_{15: 0}$, differ (Bernardet et al., 1996) (Table 1).

Overall, the results of the present study show that the new isolates from whales constitute a distinct branch and do not display a close relationship with any described Flavobacterium species (Fig. 1). Moreover, the new isolates could be distinguished from their close phylogenetic relatives on the basis of phenotypic characteristics (Table 1). Therefore, on the basis of phylogenetic and phenotypic criteria, it is evident that the new isolates merit classification within a novel species of the genus Flavobacterium, for which the name Flavobacterium ceti sp. nov. is proposed. Tests that are useful in differentiating $F$. ceti from related species sharing more than $93.0 \% 16 \mathrm{~S}$ rRNA gene sequence similarity are shown in Table 1.

\section{Description of Flavobacterium ceti sp. nov.}

Flavobacterium ceti (ce'ti. L. n. cetus whale; L. gen. n. ceti of a whale).

Cells are Gram-negative rods, $0.3 \mu \mathrm{m}$ wide and $2.0 \mu \mathrm{m}$ long, non-spore-forming and non-gliding. Grows well under aerobic conditions, weakly under microaerobic conditions and poorly under anaerobic conditions. Grows at $22-37^{\circ} \mathrm{C}$, with optimal growth at about $35{ }^{\circ} \mathrm{C}$, while no growth occurs at 42,15 or $4{ }^{\circ} \mathrm{C}$. Growth occurs on trypticase soy agar but not on MacConkey agar. Grows weakly on marine and nutrient agars after incubation at $37{ }^{\circ} \mathrm{C}$ for $48 \mathrm{~h}$. Growth occurs in brain heart infusion broth containing $3 \% \mathrm{NaCl}$ but not with 4.5 or $6.5 \%$ $\mathrm{NaCl}$. Colonies are circular, orange-pigmented, smooth and entire on Columbia blood agar after $24 \mathrm{~h}$ of incubation at $37^{\circ} \mathrm{C}$. Colonies are non-haemolytic. Nondiffusible flexirubin-type pigments are produced. Congo red is not absorbed by colonies. Catalase and oxidase are produced. Nitrate and nitrite are not reduced. Gelatin, casein and starch are degraded, but CM-cellulose, alginate, pectin and agar are not. A brown pigment is produced on tyrosine agar, although degradation of tyrosine is not detected. Aesculin, arginine, DNA and urea are not hydrolysed. Acetoin, indole and $\mathrm{H}_{2} \mathrm{~S}$ are not produced. Lysine and ornithine are not decarboxylated. Acid is not produced from D-glucose, D-mannitol, inositol, D-sorbitol, L-rhamnose, sucrose, D-melibiose, amygdalin or L-arabinose. D-Glucose, L-arabinose, D-mannose, D-mannitol, $N$-acetylglucosamine, maltose, gluconate, caprate, adipate, malate, citrate and phenylacetate are not assimilated. Valine arylamidase, leucine arylamidase, alkaline phosphatase (weak reaction), esterase lipase C8 (weak reaction), acid phosphatase (weak reaction) and naphthol-AS-BI-phosphohydrolase (weak reaction) activities are present. Arginine dihydrolase, esterase $\mathrm{C} 4$, proline arylamidase, lipase $\mathrm{C} 14$, cystine arylamidase, trypsin, $\alpha$-chymotrypsin, $\alpha$-glycosidase, $\beta$ galactosidase, $\beta$-glucuronidase, $\alpha$-glucosidase, $\beta$-glucosidase, $N$-acetyl- $\beta$-glucosaminidase, $\alpha$-mannosidase, $\alpha$-fucosidase and ornithine decarboxylase activities are absent. Cells contain menaquinone-6 (MK-6) as the major respiratory quinone. Long-chain fatty acids are of the branched and hydroxy types, with iso- $\mathrm{C}_{15: 0}$, iso- $\mathrm{C}_{17: 1} \omega 9 c$, iso- $\mathrm{C}_{17: 0} 3-\mathrm{OH}$ and summed feature $4\left(\mathrm{C}_{16: 1} \omega 7 \mathrm{c} /\right.$ iso$\left.\mathrm{C}_{15: 0} 2-\mathrm{OH}\right)$ predominating. The DNA $\mathrm{G}+\mathrm{C}$ content is 36.4-37.2 $\mathrm{mol} \%$.

The type strain, $454-2^{\mathrm{T}}\left(=\right.$ CECT $7184^{\mathrm{T}}=$ CCUG $\left.52969^{\mathrm{T}}\right)$, was isolated from the liver of a stranded beaked whale. The DNA G + C content of this strain is $36.7 \mathrm{~mol} \%$. Strains 453-2 (=CECT 7272) and 453-5 (=CECT 7271), also isolated from beaked whales, are also assigned to this species.

\section{Acknowledgements}

A. I. V. has a fellowship from the Ramon y Cajal Program (Spanish Ministry of Science and Technology/UCM). The authors thank A. Casamayor for technical assistance, the DSMZ Identification Service and Dr Brian Tindall, DSMZ, for the analysis of respiratory quinones and Dr Enevold Falsen, CCUG, University of Göteborg, Sweden, for the analysis of cellular fatty acids.

\section{References}

Arahal, D. R., García, M. T., Vargas, C., Canovas, D., Nieto, J. J. \& Ventosa, A. (2001). Chromohalobacter salexigens sp. nov., a moderately halophilic species that includes Halomonas elongata DSM 3043 and ATCC 33174. Int J Syst Evol Microbiol 51, 1457-1462.

Bergey, D. H., Harrison, F. C., Breed, R. S., Hammer, B. W. \& Huntoon, F. M. (1923). Bergey's Manual of Determinative Bacteriology. Baltimore: Williams \& Wilkins.

Bernardet, J. F. \& Bowman, J. P. (2006). The genus Flavobacterium. In The Prokaryotes: a Handbook on the Biology of Bacteria, 3rd edn, vol. 7, pp. 481-531. Edited by M. Dworkin, S. Falkow, E. Rosenberg, K. H. Schleifer \& E. Stackebrandt. New York: Springer.

Bernardet, J. F. \& Nakagawa, Y. (2006). An introduction to the family Flavobacteriaceae. In The Prokaryotes: a Handbook on the Biology of Bacteria, 3rd edn, vol. 7, pp. 455-480. Edited by M. Dworkin, S. Falkow, E. Rosenberg, K. H. Schleifer \& E. Stackebrandt. New York: Springer.

Bernardet, J. F., Segers, P., Vancanneyt, M., Berthe, F., Kersters, K. \& Vandamme, P. (1996). Cutting a Gordian knot: emended classification and description of the genus Flavobacterium, emended description of the family Flavobacteriaceae, and proposal of Flavobacterium hydatis nom. nov. (basonym, Cytophaga aquatilis Strohl and Tait 1978). Int J Syst Bacteriol 46, 128-148.

Bernardet, J. F., Nakagawa, Y. \& Holmes, B. (2002). Proposed minimal standards for describing new taxa of the family 
Flavobacteriaceae and emended description of the family. Int J Syst Evol Microbiol 52, 1049-1070.

Bowman, J. P. (2000). Description of Cellulophaga algicola sp. nov., isolated from the surfaces of Antarctic algae, and reclassification of Cytophaga uliginosa (ZoBell and Upham 1944) Reichenbach 1989 as Cellulophaga uliginosa comb. nov. Int J Syst Evol Microbiol 50, 1861-1868.

Bowman, J. P., Cavanagh, J., Austin, J. J. \& Sanderson, K. (1996). Novel Psychrobacter species from Antarctic ornithogenic soils. Int $J$ Syst Bacteriol 46, 841-848.

Cousin, S., Päuker, O. \& Stackebrandt, E. (2007). Flavobacterium aquidurense sp. nov. and Flavobacterium hercynium sp. nov., from a hard-water creek. Int J Syst Evol Microbiol 57, 243-249.

De Ley, J. \& Tijtgat, R. (1970). Evaluation of membrane filter methods for DNA-DNA hybridization. Antonie van Leeuwenhoek 36, 461-474.

Guindon, S. \& Gascuel, O. (2003). A simple, fast, and accurate algorithm to estimate large phylogenies by maximum likelihood. Syst Biol 52, 696-704.

Johnson, J. L. (1994). Similarity analysis of DNAs. In Methods for General and Molecular Bacteriology, pp. 655-681. Edited by P. Gerhardt, R. G. E. Murray, W. A. Wood \& N. R. Krieg. Washington, DC: American Society for Microbiology.

Kämpfer, P. \& Kroppenstedt, R. M. (1996). Numerical analysis of fatty acid patterns of coryneform bacteria and related taxa. Can J Microbiol 42, 989-1005.

Kim, B.-Y., Weon, H.-Y., Cousin, S., Yoo, S.-H., Kwon, S.-W., Go, S.-J. \& Stackebrandt, E. (2006). Flavobacterium daejeonense sp. nov. and Flavobacterium suncheonense sp. nov., isolated from greenhouse soils in Korea. Int J Syst Evol Microbiol 56, 1645-1649.

Kimura, M. (1980). A simple method for estimating evolutionary rates of base substitutions through comparative studies of nucleotide sequences. J Mol Evol 16, 111-120.

Kumar, S., Tamura, K. \& Nei, M. (2004). MEGA3: integrated software for molecular evolutionary genetics analysis and sequence alignment. Brief Bioinform 5, 150-163.

Marmur, J. (1961). A procedure for the isolation of deoxyribonucleic acid from microorganisms. J Mol Biol 3, 208-219.

Marmur, J. \& Doty, P. (1962). Determination of the base composition of deoxyribonucleic acid from its thermal denaturation temperature. J Mol Biol 5, 109-118.

McCammon, S. A., Innes, B. H., Bowman, J. P., Franzmann, P. D., Dobson, S. J., Holloway, P. E., Skerratt, J. H., Nichols, P. D. \& Rankin, L. M. (1998). Flavobacterium hibernum sp. nov., a lactose-utilizing bacterium from a freshwater Antarctic lake. Int J Syst Bacteriol 48, 1405-1412.
Nogi, Y., Soda, K. \& Oikawa, T. (2005). Flavobacterium frigidimaris sp. nov., isolated from Antarctic seawater. Syst Appl Microbiol 28, 310-315.

Page, R. D. M. (1996). TreeView: an application to display phylogenetic trees on personal computers. Comput Appl Biosci 12, 357-358.

Pearson, W. R. (1994). Using the FASTA program to search protein and DNA sequence databases. Methods Mol Biol 24, 307-331.

Rasmussen, S. W. (1995). DNATools, a software package for DNA sequence analysis. Copenhagen: Carlsberg Laboratory.

Saitou, N. \& Nei, M. (1987). The neighbor-joining method: a new method for reconstructing phylogenetic trees. Mol Biol Evol 4, 406-425.

Smibert, R. M. \& Krieg, N. R. (1994). Phenotypic characterization. In Methods for General and Molecular Bacteriology, pp. 607-653. Edited by P. Gerhardt, R. G. E. Murray, W. A. Wood \& N. R. Krieg. Washington, DC: American Society for Microbiology.

Van Trappen, S., Mergaert, J. \& Swings, J. (2003). Flavobacterium gelidilacus sp. nov., isolated from microbial mats in Antarctic lakes. Int J Syst Evol Microbiol 53, 1241-1245.

Van Trappen, S., Vandecandelaere, I., Mergaert, J. \& Swings, J. (2004). Flavobacterium degerlachei sp. nov., Flavobacterium frigoris sp. nov. and Flavobacterium micromati sp. nov., novel psychrophilic bacteria isolated from microbial mats in Antarctic lakes. Int J Syst Evol Microbiol 54, 85-92.

Vancanneyt, M., Segers, P., Torck, U., Hoste, B., Bernardet, J.-F., Vandamme, P. \& Kersters, K. (1996). Reclassification of Flavobacterium odoratum (Stutzer 1929) strains to a new genus, Myroides, as Myroides odoratus comb. nov. and Myroides odoratimimus sp. nov. Int J Syst Bacteriol 46, 926-932.

Vela, A. I., Collins, M. D., Lawson, P. A., García, N., Domínguez, L. \& Fernández-Garayzábal, J. F. (2005). Uruburuella suis gen. nov., sp. nov., isolated from clinical specimens of pigs. Int J Syst Evol Microbiol 55, 643-647.

Wayne, L. G., Brenner, D. J., Colwell, R. R., Grimont, P. A. D., Kandler, O., Krichevsky, M. I., Moore, L. H., Moore, W. E. C., Murray, R. G. E. \& other authors (1987). International Committee on Systematic Bacteriology. Report of the ad hoc committee on reconciliation of approaches to bacterial systematics. Int J Syst Bacteriol 37, 463-464.

Yi, H. \& Chun, J. (2006). Flavobacterium weaverense sp. nov. and Flavobacterium segetis sp. nov., novel psychrophiles isolated from the Antarctic. Int J Syst Evol Microbiol 56, 1239-1244.

Yoon, J., Maneerat, S., Hawai, F. \& Yokota, A. (2006). Myroides pelagicus sp. nov., isolated from seawater in Thailand. Int J Syst Evol Microbiol 56, 1917-1920. 